\author{
Trends in Heavy Oil Production and Refining in California NIPER--587 \\ Topical Report \\ DE92 001056 \\ By \\ D. K. Olsen \\ E. B. Ramzel \\ R. A. Pendergrass II
}

July 1992

Work Performed Under Cooperative Agreement No. DE-FC22-83FE60149

\author{
Prepared for \\ U.S. Department of Energy \\ Assistant Secretary for Fossil Energy
}

Thomas B. Reid, Project Manager

Bartlesville Project Office

P. O. Box 1398

Bartlesville, OK 74005

\author{
Prepared by \\ IIT Research Institute \\ National Institute for Petroleum and Energy Research \\ P. O. Box 2128 \\ Bartlesville, OK 74005
}




\section{TABLE OF CONTENTS}

Page

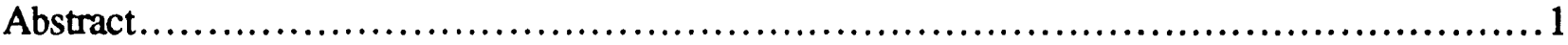

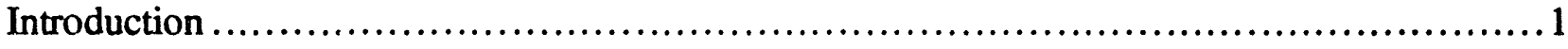

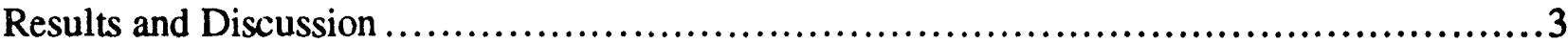

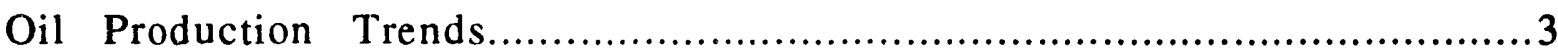

California Heavy Oil Contribution to Projected Thermally Produced Oil................. 10

Marketing, Transportation and Refining........................................... 11

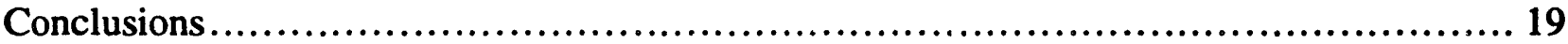

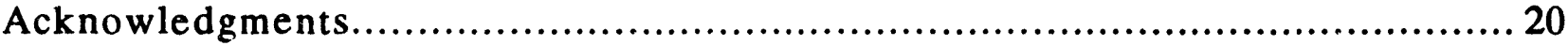

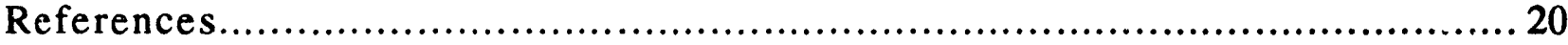

\section{TABLES}

1. Daily California oil production in barrels by API gravity ............................9

2. Crude oil prices of the past decade .................................................... 13

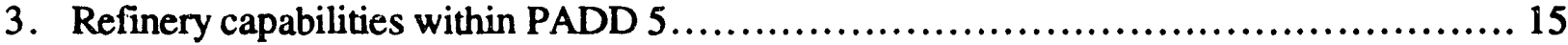

\section{ILLUSTRATIONS}

1. California map showing the three major oil regions ................................. 4

2. California oil production since 1940 showing percent of total oil that is heavy oil .........4

3. California oil production since 1940 showing oil production corresponding with the number of active oil wells .....................................................

4. Total oil production by regions within California...............................................5

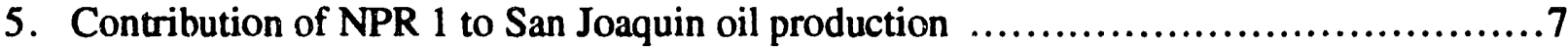

6. Contribution of NPR 1 to total California production...............................

7. California production showing major contribution of heavy oil .......................8

8. California daily oil production, inclusive under each degree API cutoff..................8

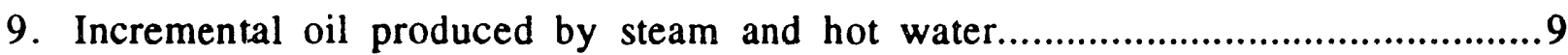

10. Projected production rated for thermally produced oil from the 1984 NPC study ........ 10

11. Projected sensitivity of thermal recovery production rate to nominal crude oil price from the 1984 NPC study ....................................................... 12

12. Average yearly oil price per barrel and ratio to Kern River oil price......................... 12

13. Trends in oil gravity for the past decade in each PADD...................................... 14

14. Trends in oil sulfur content for the past decade in each PADD................................ 14 


\section{ILLUSTRATIONS-Continued}

\section{Page}

15. API gravity and sulfur content of domestic and imported crude oil being processed in U.S. refineries .................................................................... 17

16. U.S. crude oil demand, imports, and U.S. oil production compared to California

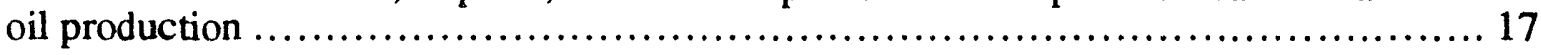

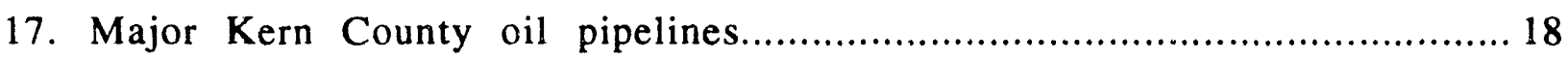




\title{
TRENDS IN HEAVY OIL PRODUCTION AND REFINING IN CALIFORNIA
}

\author{
By D. K. Olsen, ${ }^{1}$ E.B. Ramzel, ${ }^{1}$ and R. A. Pendergrass $\Pi^{2}$
}

\begin{abstract}
This report is one of a series of publications assessing the feasibility of increasing domestic heavy oil production and is part of a study being conducted for the U.S. Department of Energy. This report summarizes trends in oil production and refining in California.

Heavy oil $\left(10^{\circ}\right.$ to $20^{\circ}$ API gravity) production in California has increased from $20 \%$ of the state's total oil production in the early 1940 s to $70 \%$ in the late 1980 s. In each of the three principal petroleum producing districts (Los Angeles Basin, Coastal Region, and San Joaquin Valley) oil production has peaked and then declined at different times throughout the past 30 years. Thermal production of heavy oil has contributed to making California the largest producer of oil by enhanced oil recovery processes in spite of low oil prices for heavy oil and stringent environmental regulation. Opening of Naval Petroleum Reserve No. 1, Elk Hills (CA) field in 1976, brought about a major new source of light oil at a time when light oil production had greatly declined. Although California is a major petroleum-consuming state, in 1989 the state used 13.3 billion gallons of gasoline or $11.5 \%$ of U.S. demand but it contributed substantially to the Nation's energy production and refining capability. California is the recipient and refines most of Alaska's 1.7 million barrel per day oil production. With California production, Alaskan oil, and imports brought into California for refining, California has an excess of oil and refined products and is a net exporter to other states. The local surplus of oil inhibits exploitation of California heavy oil resources even though the heavy oil resources exist. Transportation, refining, and competition in the market limit full development of California heavy oil resources.
\end{abstract}

\section{INTRODUCTION}

This report summarizes a segment of research undertaken as part of a national assessment of the feasibility of increasing domestic heavy oil production, a study being conducted by NIPER for the U.S. Department of Energy. Heavy oil is defined as having gas-free viscosity of $>100$ and $<10,000 \mathrm{MPas}$ (centipoise, cP) inclusive at original reservoir temperature or a density of 943

${ }^{1}$ National Institute for Petroleum and Energy Research.

2 University of Oklahoma, AWU Summer Fellow at NIPER. 
$\mathrm{kg} / \mathrm{m}^{3}$ (20 API gravity) to $1,000 \mathrm{~kg} / \mathrm{m}^{3}\left(10^{\circ}\right.$ API gravity) inclusive at $15.6^{\circ} \mathrm{C}\left(60^{\circ} \mathrm{F}\right) .^{1}$ The objectives of this nationwide heavy oil feasibility study are (1) to investigate from secondary data the known heavy oil resources; (2) to screen this resource for potential thermal recovery or other enhanced oil recovery (EOR) techniques; and (3) to evaluate various economic facets (refining, transportation, environmental, etc.) that may impact the expansion of heavy oil production. This portion of the study was undertaken because comparisons are often made between the success of thermal enhanced oil recovery, TEOR, (cyclic steam, steamflooding, and in situ combustion) technology in California and that of other parts of the world. California has become a model because TEOR has successfully been used to produce significant heavy oil.2-3 This report provides a background for comparison by providing a summary of production data (through 1990) and refining data. This study was undertaken to quantify on a regional basis the contribution made by TEOR to the oil production of California. A separate report will cover the geology and reservoir properties of the heavy oil reservoirs in Califomia.

The California Department of Conservation, Division of Oil and Gas (DOG) ${ }^{4-6}$ and the Conservation Committee of California Oil Producers (CCCOP) $)^{7-11}$ compile reports on the oil and gas production within California. Together, their reports constitute one of the most complete annual summaries of oil production of any state. The Conservation Committee's tracking of oil production by reservoir and by API gravity is only possible by strong support from member producing companies, the compliance of companies with state requirements for reporting, and great effort by the Conservation Committee of Califomia Oil Prorducers. In many other states, only total production by field or by county is available. To obtain reservoir production data or the API gravity of the oil in these states, individual run tickets listing barrels of oil sold from a given lease would have to be correlated.

During the early 1960 s, the use of steam or in situ combustion to recover viscous heavy oil was just beginning, and both major companies and independents conducted numerous field pilots and carefully guarded their data. Since that time, TEOR technology has improved in efficiency and has become the major enhanced oil recovery method in the United States.

Based on the data compiled as the biennial United States EOR Production Report published by Oil \& Gas Journal, ${ }^{2}$ TEOR accounts for $70 \%$ [454,212 barrels of oil per day (BOPD)] of all the domestic EOR oil (656,700 BOPD) produced. California accounts for $98 \%$ ( 445,557 BOPD) of all TEOR oil. The rest of the country contributes only 8,655 BOPD. ${ }^{2}$ If TEOR production is broken down by process, California produces $98.7 \%$ (448,122 BOPD) of the oil produced by steam and hot water, but only $54 \%$ (3,300 BOPD) of the oil produced by in situ combustion. ${ }^{2}$ The biennial EOR summary is compiled from information contributed voluntarily, and the numbers do not coincide with those recently reported by $\operatorname{CCCOP~}(1991)^{7}$ which is believed to be a more accurate summary of the TEOR oil production in California. Recent reviews by Blevins 12 and 
Schmidt ${ }^{13}$ give assessments of the maturity of TEOR, its current status, and future needs. Most of their assessments are based upon the performance of steam to reduce the viscosity of California asphaltic heavy crude oils.

California is a unique state that not only produces light and heavy oil, but it also refines most of the production (1.7 million BOPD) from Alaska's North Slope (ANS) $27^{\circ}$ API gravity oil. ${ }^{14-17}$ California is also one of the best and largest volume petroleum marketing regions in the United States. In 1989, California's annual gasoline consumption was 13.3 billion gallons (33 million gal/day). This is the largest volume of any state in the Nation and $11.5 \%$ of total U.S. consumption. 18

\section{RESULTS AND DISCUSSION}

\section{Oil Production Trends}

Figure 1 is a map of California showing the three major oil producing regions (San Joaquin, Coastal, and Los Angeles) that have helped California become the leading domestic producer of heavy oil. Total oil production for California, as shown in Fig. 2, illustrates the overall contribution that heavy oil has made to the state's oil production. 8 Figure 2 shows oil production on a daily basis as well as the percent of total California oil produced that is within the $10^{\circ}$ to $20^{\circ}$ API gravity range. Total oil production peaked in the mid 1980s. During the past 50 years, California was able to double the oil production of the early 1940s. In the decade of the 1940s, heavy oil accounted for 20 to $30 \%$ of the total oil production. Concurrent with the development of thermal oil recovery processes in the early 1960s, heavy oil production began to gradually increase the fraction it contributed to total oil production. Except for periods in the late 1960s and between 1975 and 1978, the percent of heavy oil produced in California relative to total oil production has increased. The fraction that heavy oil contributes peaked in 1987 at $71 \%$ and has remained nearly constant in spite of significantly reduced total oil production since 1985 . When the same data are compared with the number of producing oil wells (Fig. 3 ), there are similar trends in oil production and the number of wells. ${ }^{8}$ The number of oil wells producing heavy oil has steadily increased since 1940 and peaked in the mid 1980s. The number of wells producing light oil peaked in the late 1950 s.

Total production for each of the three major California regions is depicted in Fig. 4.9 Oil production in the Coastal region has slowly declined over the past 30 years with temporary increases coinciding with or following higher oil prices. Oil production in the Los Angeles Basin has been steadily declining since the late 1960s and is now less than half of peak production. Pressure from population, environmental constraints, and higher water cuts on mature waterfloods are some of the factors causing declining oil production. 


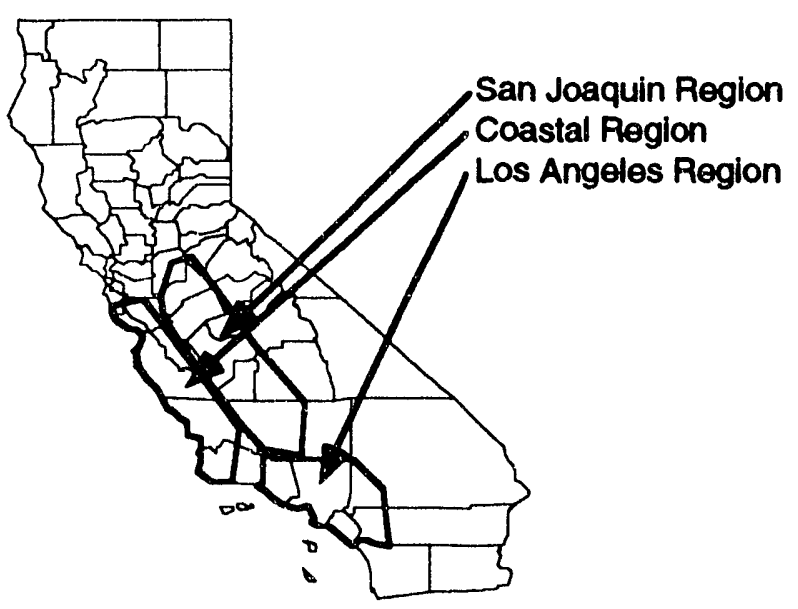

FIGURE 1. - California map showing the three major oil regions.

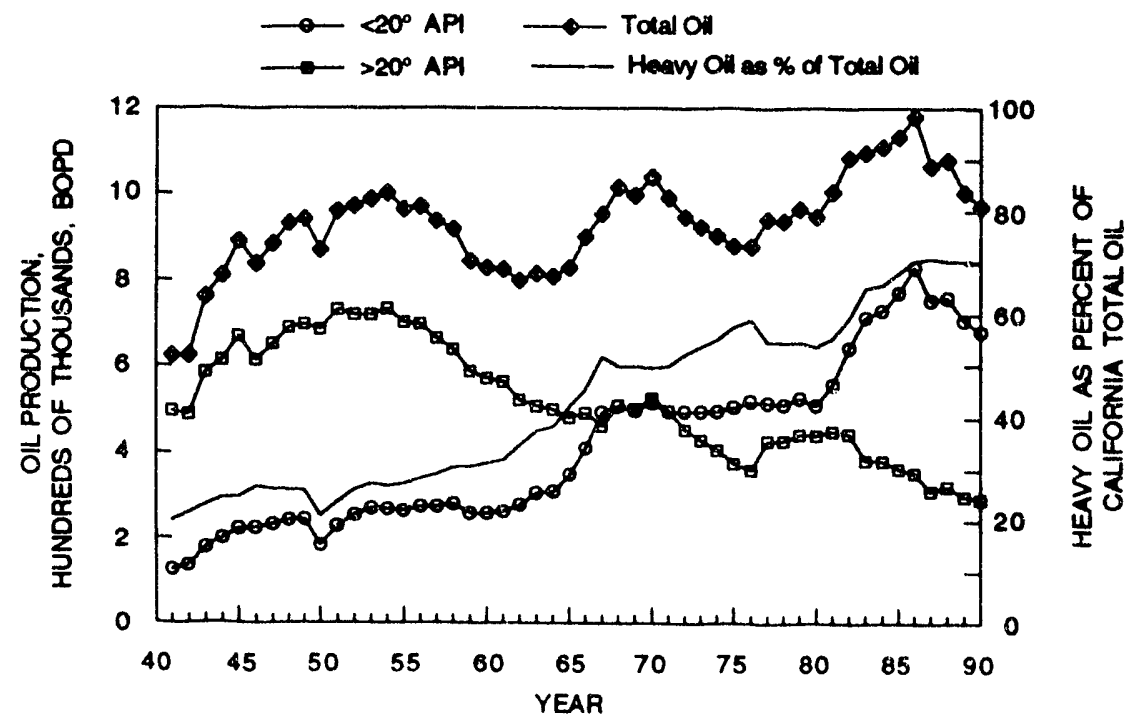

FIGURE 2. - California oil production since 1940 showing the percent of total oil that is heavy oil. 


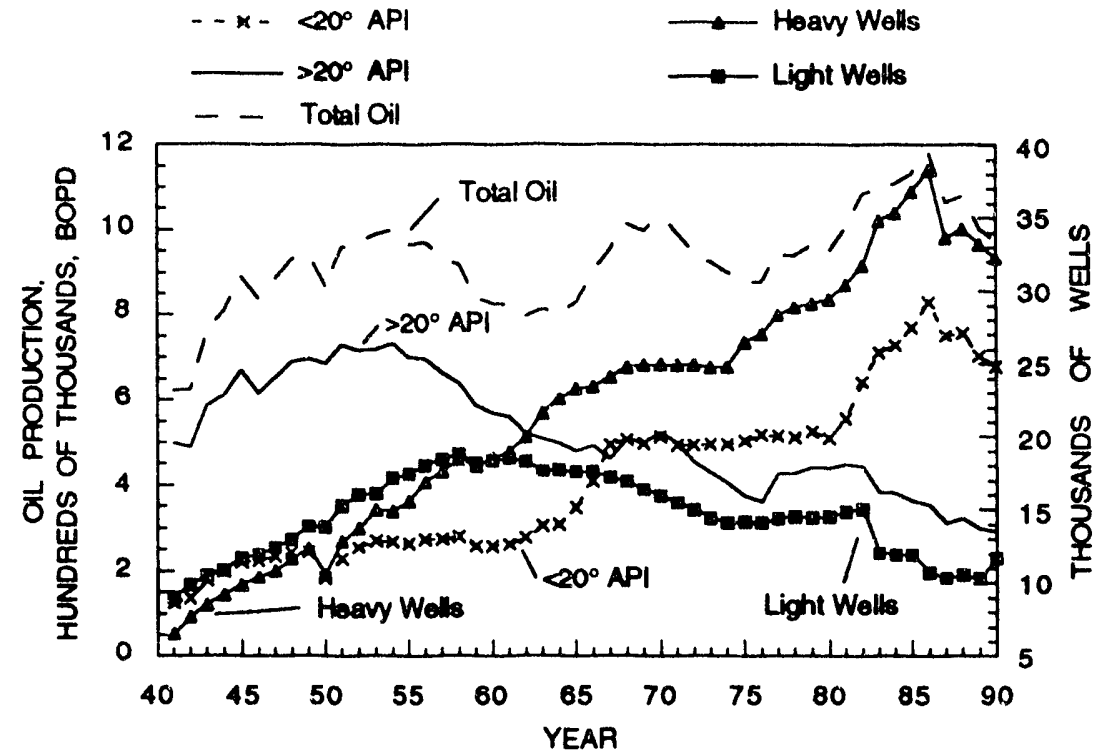

FIGURE 3. - California oil production since 1940 showing oil production with the number of active oil wells.

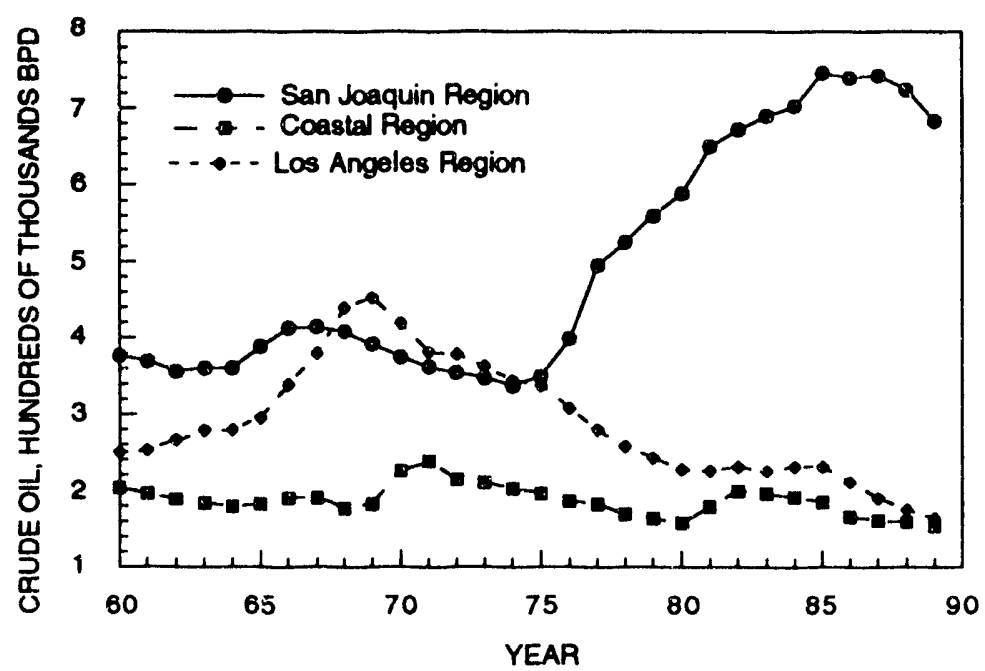

FIGURE 4. - Total oil production by regions within California. 
Oil production in the San Joaquin Region has demonstrated the most marked increase. This increase is due to thermal heavy oil production and new oil production from Naval Petroleum Reserve No. 1 at Elk Hills (Fig. 5).7-10,19 This giant light oil field has made a significant contribution to San Joaquin and the total oil production in California (Fig. 6) since it was opened for commercial production in 1976.7-10,19 In both Figs. 5 and 6, the light oil contributed by NPR No. 1 operations has been subtracted from the total oil produced in the San Joaquin Valley of California. In Fig. 5, the heavy oil production for the San Joaquin Valley for the past few years has been available and is plotted. When the total oil production in the San Joaquin Basin is plotted and the contribution of light oil production from Elk Hills is subtracted (black diamond), the light oil produced in the basin in other fields can be calculated. The difference between NPR No. 1 production and San Joaquin heavy oil production is the other light oil produced in the Basin which is less than 60,000 BOPD. A similar comparison, but over a longer period of time, is shown in Fig. 6. On a statewide basis, it shows the growth of light oil production at NPR No. 1 and the decline in overall light oil production during the past few years. $7-10,19$ Without Elk Hills light oil, the state would have been producing 78\% heavy oil instead of $70 \%$ heavy oil in 1989.

The Conservation Committee of California Producers has tracked oil production by API gravity on a statewide and regional basis for many years. Since 1986, they have compiled production data by reservoir and by API gravity. 7-11 This allows analysis of the contribution of each oil gravity range, as shown in Figs. 7 and 8. A tabular listing by region for the past few years is shown in Table 1 . This tabular listing corrects previously published data ${ }^{9-11}$ and reflects NIPER's correction for having Midway-Sunset (CA) and South Belridge (CA) fields assigned to the incorrect API gravity range in 1986 and 1987. During the past 15 years, the percent of total production by API gravity range, Fig. 7 , shows that light oil, $>20^{\circ}$ API, has slowly declined whereas heavy oil production has increased. Figure 8 shows California daily oil production inclusive under each degree API; thus, the contribution of each oil gravity range can be seen in comparison to the total oil mix. ${ }^{8}$

Heavy oil is produced by primary production, by waterflooding deeper, hotter reservoirs such as the Ranger zone in Wilmington (CA) field, and by thermal methods which reduce the viscosity of the oil. The Conservation Committee of California Oil Producers has calculated the incremental oil produced by steam and hot water relative to the remaining oil produced, as shown in Fig. 9.7-8

In 1990, Midway-Sunset (CA) field production exceeded South Belridge (CA) field as the top oil producer in California and the lower 48 states. Midway-Sunset produced its second billion barrel in January 1991. Only three other U.S. fields [Prudhoe Bay (AK), East Texas (TX), and Wilmington (CA)] have produced more than 2 billion barrels of oil. 


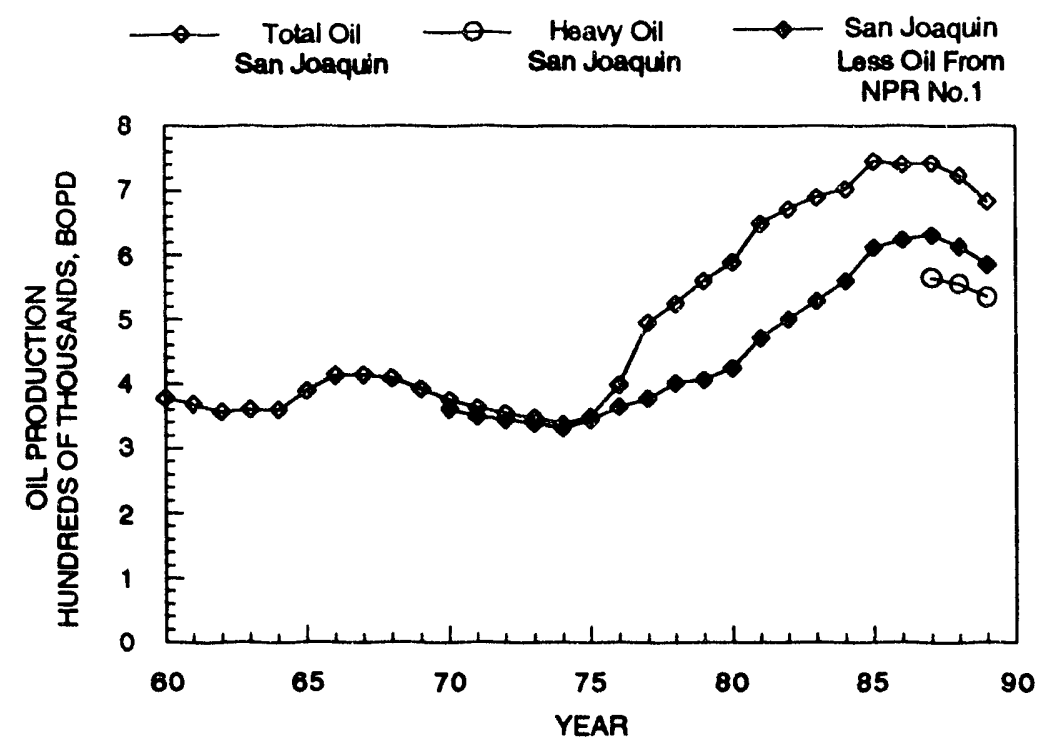

FIGURE 5. - Contribution of NPR 1 to San Joaquin oil production.

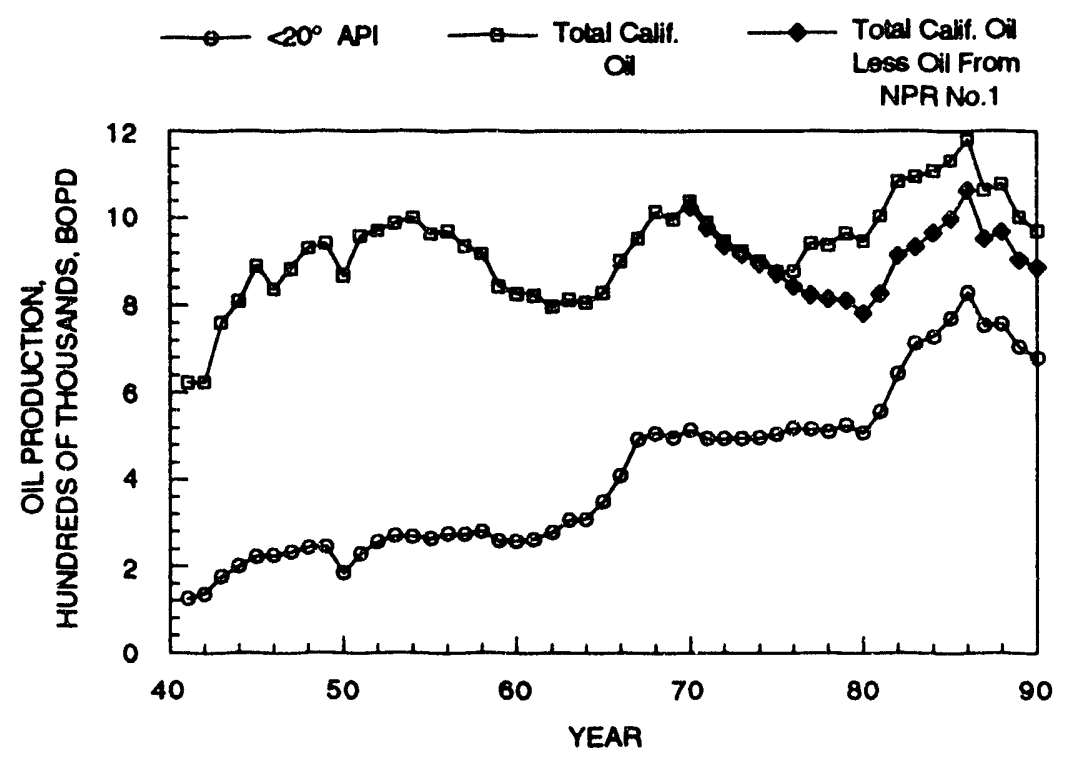

FIGURE 6. - Contribution of NPR 1 to total California production. 


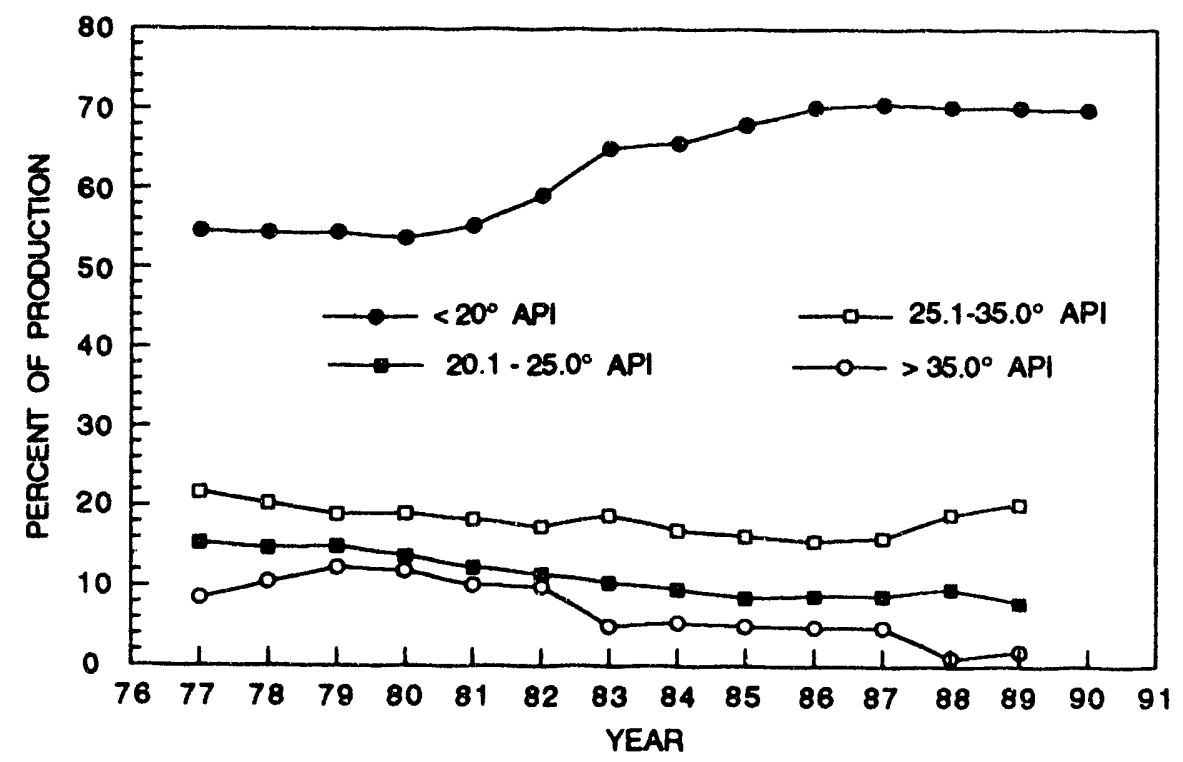

FIGURE 7. - California production showing major contribution of heavy oil.

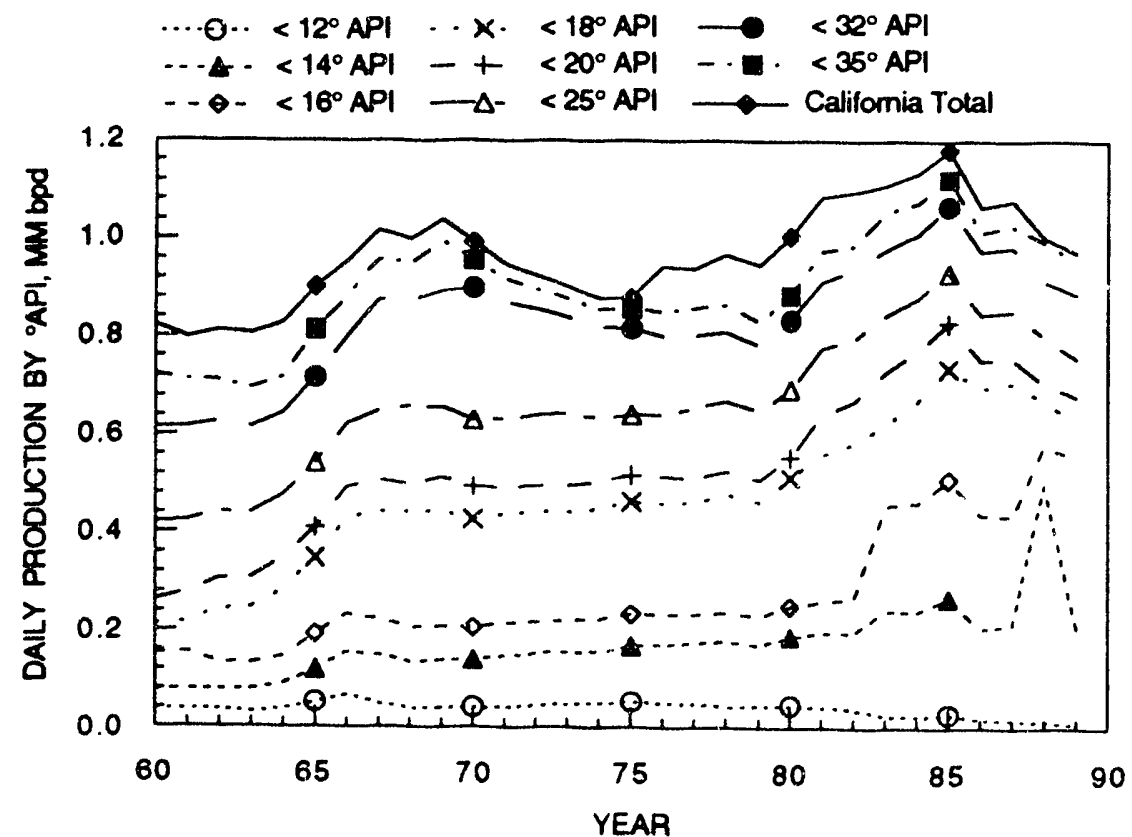

FIGURE 8. - California daily oil production, inclusive under each degree API cutoff. 
TABLE 1. - Daily California oil production in barrels by API gravity (Modified from Conservation Committee, 1986-1990)

\begin{tabular}{|c|c|c|c|c|c|c|c|c|}
\hline \multirow{2}{*}{$\begin{array}{c}\text { Gravity } \\
\text { range }\end{array}$} & \multicolumn{8}{|c|}{ Barrels of Oil Produced Per Day by APL Grovity } \\
\hline & $5.0-9.9$ & $10.0-14.9$ & $15.0-19.9$ & $20.0-24.9$ & $25.0-29.9$ & $30.0-34.9$ & $35.0-39.9$ & $40 \&$ Over \\
\hline \multicolumn{9}{|l|}{ 1986: } \\
\hline Valley & 0 & 504,770 & 56,941 & 24,827 & 28,367 & 70,953 & 49.552 & 4,416 \\
\hline Coast & 12,778 & 28,781 & 43,181 & 19,354 & 35,953 & 24,153 & 708 & 413 \\
\hline Basin & 0 & 15.344 & 115.358 & 50.962 & 21.722 & 7.334 & 150 & 226 \\
\hline Total & 12,778 & 548,895 & 215,480 & 95,143 & 86,042 & 102,440 & 50,410 & 5,055 \\
\hline \multicolumn{9}{|l|}{ 1987: } \\
\hline Valley & 43 & 516,947 & 46,727 & 23,921 & 32,211 & 71,774 & 47,209 & 3,932 \\
\hline Coast & 11,677 & 24,924 & 49,520 & 29,816 & 24,991 & 18,893 & 566 & 389 \\
\hline Basin & & 16.483 & 105.900 & 41.413 & 22.627 & 2.773 & 145 & 193 \\
\hline Total & 11.720 & 558,354 & 202,147 & 95,150 & 79,829 & $\overline{93,440}$ & 47,920 & 4,514 \\
\hline \multicolumn{9}{|l|}{ 1988: } \\
\hline Valley & 0 & 529,101 & 25,890 & 26,423 & 27,852 & 107,071 & 9,049 & 478 \\
\hline Cosst & 6,547 & 25,572 & 48,143 & 33,906 & 25,942 & 18,203 & 506 & 440 \\
\hline Basin & & 14.856 & 90.700 & 44.991 & 18.902 & 4.576 & 641 & 116 \\
\hline Total & 6,547 & 569,529 & 164,733 & 105,320 & 72,696 & 129,850 & 10,196 & $\overline{1,034}$ \\
\hline \multicolumn{9}{|l|}{ 1989: } \\
\hline Valley & 0 & 506,812 & 26,798 & 23,442 & 22,871 & 93,963 & 7,966 & 439 \\
\hline Coast & 4,677 & 20,910 & 49,736 & 29,936 & 30,303 & 16,936 & 508 & 433 \\
\hline Basin & & 13.956 & 83.002 & 42.807 & 18.008 & 4.806 & 605 & 121 \\
\hline Total & 4,677 & 541,678 & 159,536 & 96,185 & 71,182 & 115,705 & 9,079 & 993 \\
\hline \multicolumn{9}{|l|}{ 1990: } \\
\hline Valley & 0 & 472,391 & 28,240 & 18,788 & 58,859 & 81,682 & 6,612 & 412 \\
\hline Coast & 3,212 & 21,666 & 42,154 & 29,493 & 29.605 & 16,702 & 413 & 492 \\
\hline Basin & & 13,493 & 76.445 & 37.445 & 16.594 & 4.554 & 597 & 21 \\
\hline Total & 3,212 & 507,551 & 146,841 & 85,727 & 105,059 & 103,184 & 7,623 & 1,000 \\
\hline
\end{tabular}

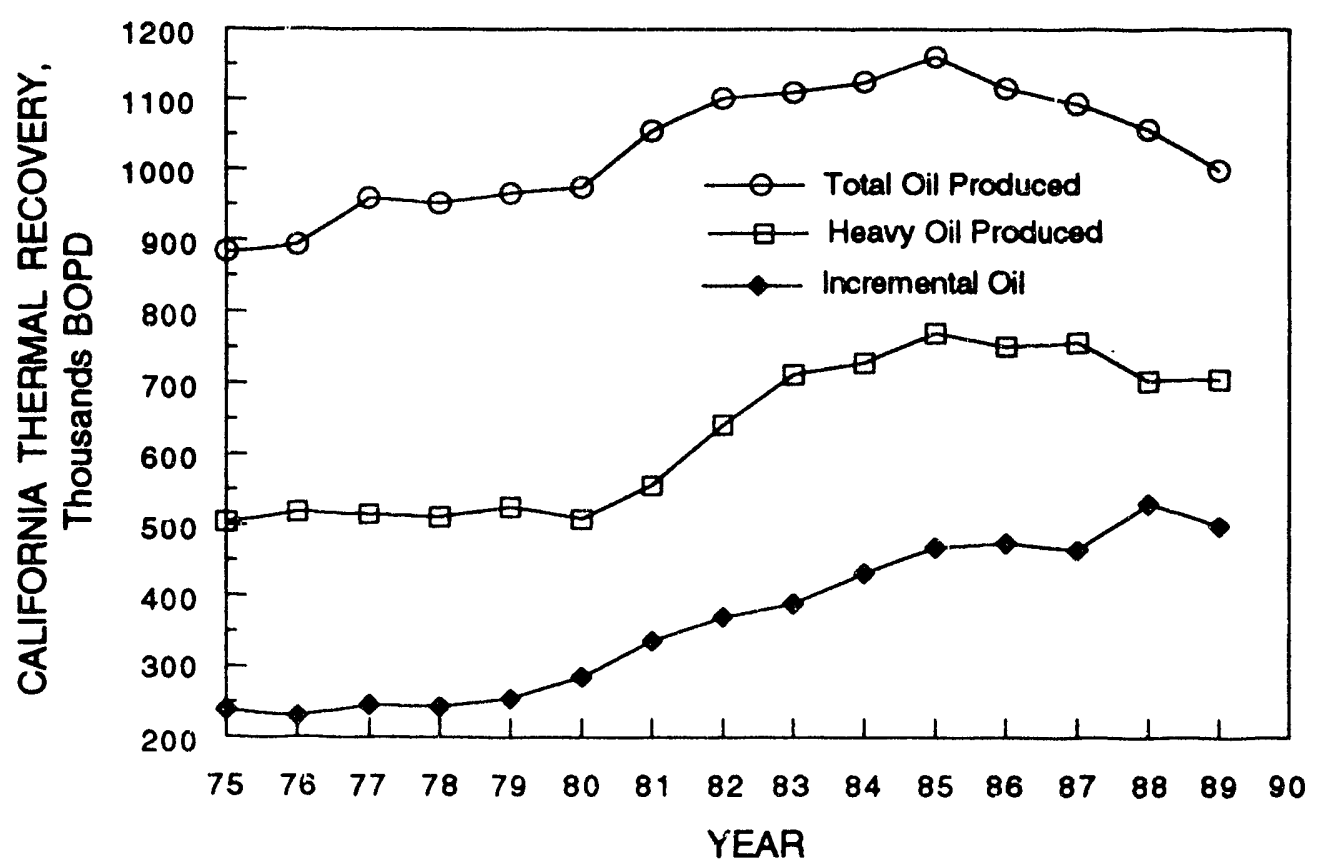

FIGURE 9. - Incremental oil produced by steam and hot water. 


\section{Culifornia Heavy Oil Contribution to Projected Thermally Produced Oil}

Domestic heavy oil production has been estimated at between 750,000 and 800,000 BOPD, ${ }^{20}$ based on analysis of the the heavy oil database being compiled by NIPER. The 1984 National Petroleum Council (NPC) Enhanced Oil Recovery study, ${ }^{3}$ projected thermally produced oil (principally heavy oil, but also includes thermal production of light oil as shcwn in Fig. 10). Current production levels of thermally produced oil fall below even 1984 projections for both implemented or advanced technology. These NPC projections (Fig. 37 of reference 3) were based upon a $\$ 30 / \mathrm{bbl}$ nominal crucle sil price and $10 \%$ minimum rate of return. With short lived exceptions, the price of crude vil has been substantially lower than $\$ 30$ since 1986 and has contributed to weak investment in thermal oil production. There have been some notable exceptions in California by those companies which are vertically integrated (i.e., companies having their own resources, production technology, heated pipelines, California refinery capacity to handle refining heavy oil, and service stations to market transportation fuels). ${ }^{21}$

To achieve the projected thermally produced oil production rate forecast in the 1984 NPC study, the heavy oil production in California would have to significantly increase because California has both the oil resource and production/transportation/refining infrastructure. Achieving the projected NPC goals is doubtful considering oil production trends (within

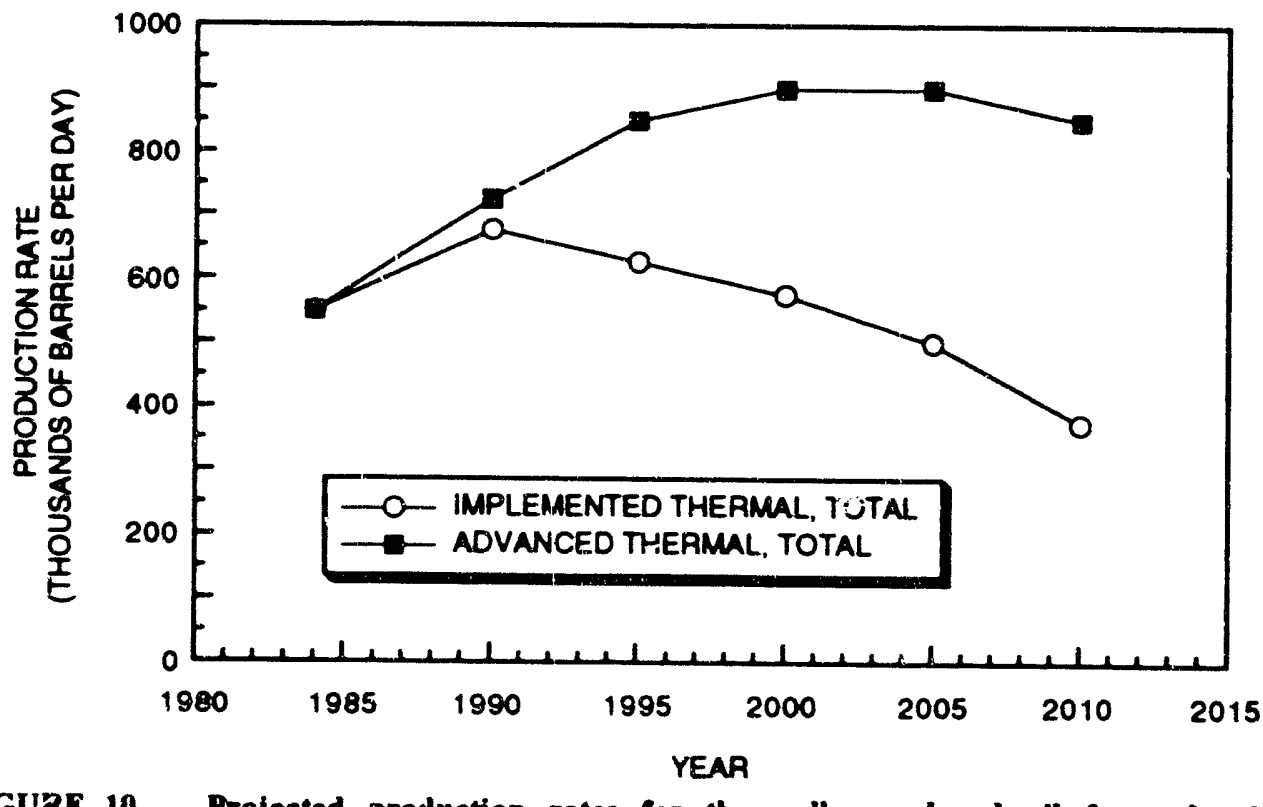

FIGURE 10. - Projected production rates for thersully produced oil from the 1984 NPC study. Comparison of implemented and adranced technology rates - at $530 / \mathrm{bb}$ and $10 \%$ minimum rate of return. 
California, the U.S. and the world) within recent years and low oil prices. The 1984 NPC study ${ }^{3}$ cautioned that

"...the study was conducted by experts in the field of enhanced oil recovery and other specialists from the petroleum industry, the resulting ultimate recoveries and production rate projections are nonetheless subject to a great deal of uncertainty. Comprehensive studies tend to converge on a best-estimate answer. The shortcomings of such a rigorous approach is not what is included in the analysis but the unknowns that are either outside the scope of investigation, or that cannot be precisely determined. These factors lie in the areas of economics, technology, and methodology. While there are a great many factors that may contribute to the overall economic uncertainty, oil price is considered the most significant." 3

The oil pricing and base case used in the 1984 NPC study used "Both present (1983) and anticipated oil prices 'which' substantially affect EOR activity. The results of the $\$ 30$ per barrel base case are strongly influenced by the events that occurred from 1978 to 1982, when the real price of oil approached $\$ 40$ per barrei and was projected to rise even higher. EOR projects benefited and gained much momentum during this time, as shown by the substantial investments made to develop $\mathrm{CO}_{2}$ resources and pipeline systems to serve the miscible flood projects in the West Texas area. Also, expansions were made to most of the large steamflood projects in California. This increased activity became part of the ongoing EOR base upon which the study results are constructed." 3

A better correlation of projected performance in the 1984 NPC study is with implemented thermal technology and $\$ 20$ per barrel oil as shown in Fig. $11 .^{3}$ For most of the time period since 1986, the posted price for California heavy oil has been substantially lower than the lowest price scenario considered in the 1984 NPC study.

\section{Marketing, Transportation and Refining}

The dramatic drop in oil prices in 1986 is illustrated in Fig. 12 and Table 2, which show oil prices and ratios of oil prices between Arab light and Arab heavy, West Texas Intermediate (WTI) crude, and California Kem River (KR) oil. ${ }^{22}$ The oil prices per barrel have generally trended upward since 1988. For short periods of time during the Gulf War, heavy oil price exceeded $\$ 20 / \mathrm{bbl}$, but recent oversupply pushed KR to $\$ 10.00 / \mathrm{bbl}$ in January 1992 when the WTI posted price was $\$ 16.50 / \mathrm{bbl} .15,23 \mathrm{Kern}$ County heavy oil, $13^{\circ} \mathrm{API}$, has averaged about two-thirds of the price of WTI over much of the past decade. The price ratios between Kern River crude and Arab crudes tend to be increasing, whereas the price ratios between Kern River and WTI remain at about two-thirds. Kern County's $13^{\circ}$ API heavy oil has historically (previous 25 years) sold for about 


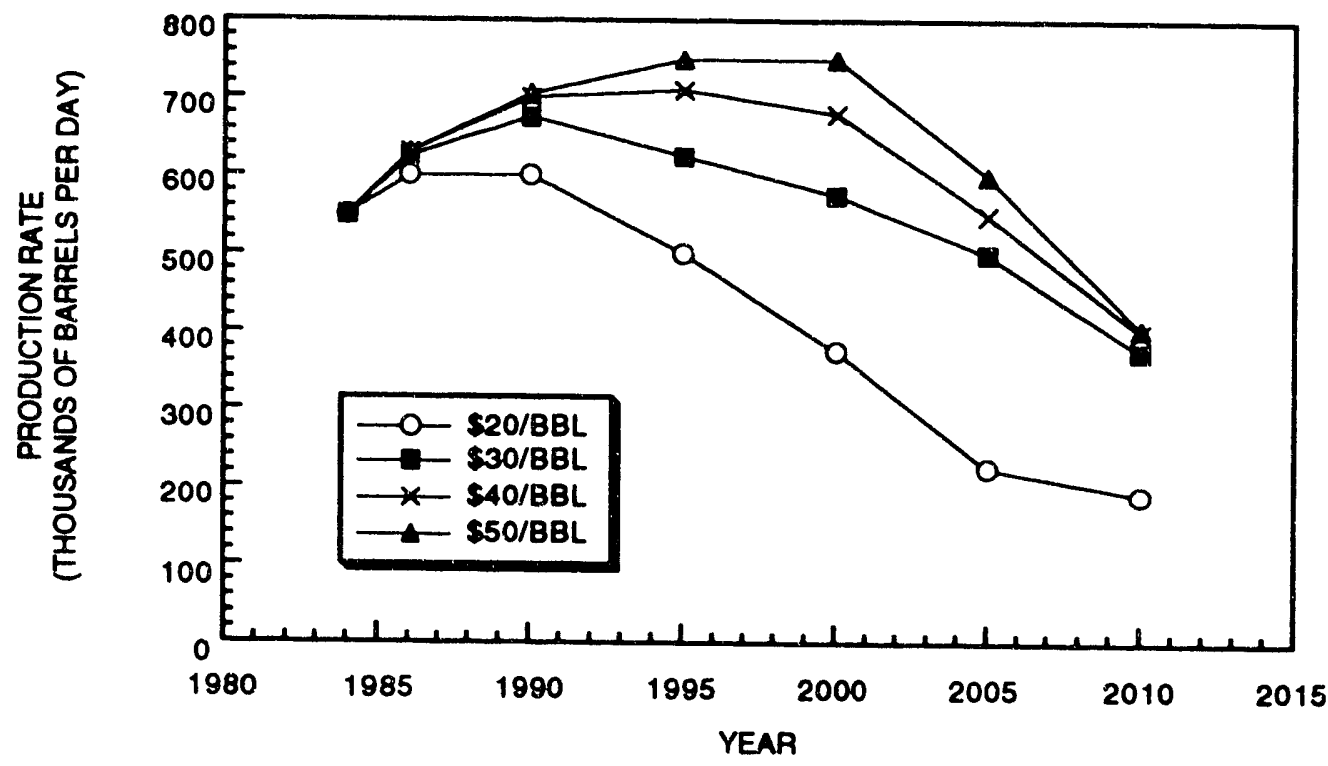

FIGURE 11. - Projected sensitivity of thermal recovery production rate to nominal crude oil price (constant 1983 dollars with 10\% minimum rate of return) from the 1984 NPC study-Implemented Technology.

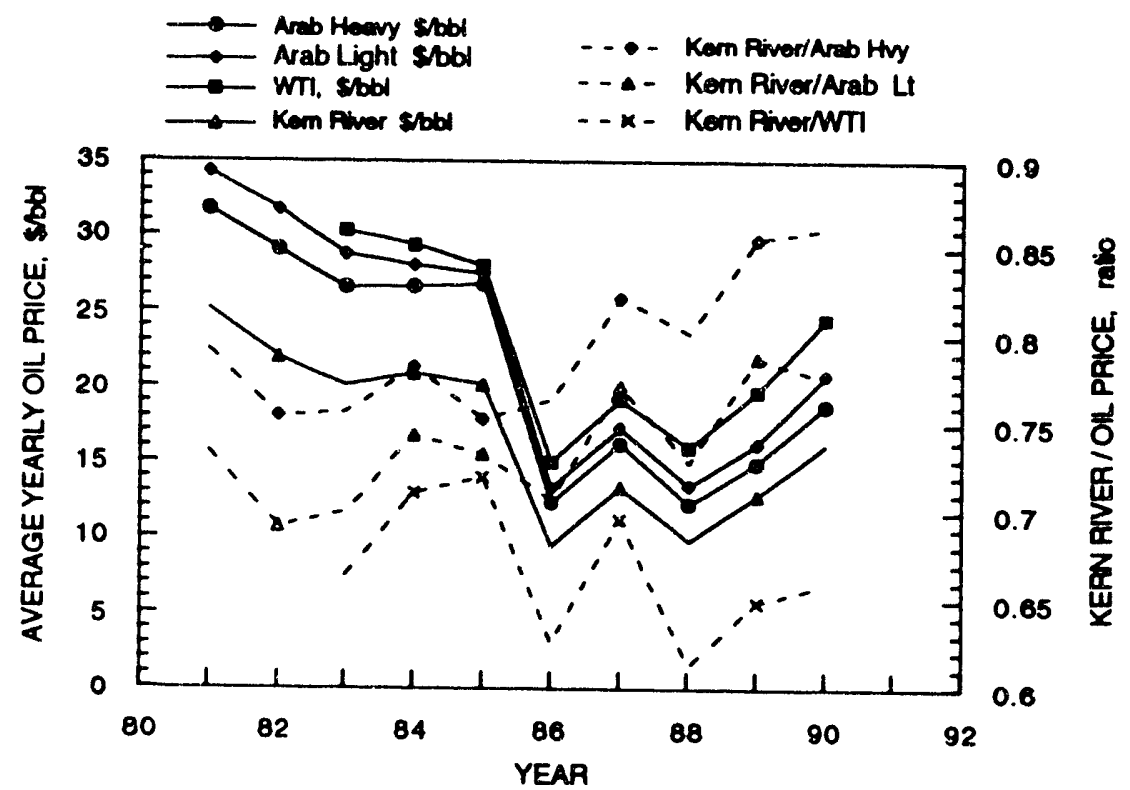

FIGURE 12. - Average yearly oil price per barrel and ratio to Kern River oil price. 22 
TABLE 2. - Crude oil prices of the past decade 22

\begin{tabular}{|c|c|c|c|c|c|c|c|}
\hline Year & $\begin{array}{c}\text { Arab } \\
\text { Heavy, } \\
\text { S/bbl }\end{array}$ & $\begin{array}{c}\text { Arab } \\
\text { Light, } \\
\$ / b b 1\end{array}$ & $\begin{array}{c}\text { West } \\
\text { Texas } \\
\text { Iatermediate, } \\
\$ / b b \mid\end{array}$ & $\begin{array}{l}\text { Kera } \\
\text { River, } \\
\text { S/bbl }\end{array}$ & $\begin{array}{c}\text { K.R.I } \\
\text { Arab } \\
\text { Heavy } \\
\text { ratio }\end{array}$ & $\begin{array}{l}\text { K.R.I } \\
\text { Arab } \\
\text { Light } \\
\text { Ratio }\end{array}$ & $\begin{array}{l}\text { K.R.I } \\
\text { WTII } \\
\text { ratio }\end{array}$ \\
\hline $\begin{array}{l}1981 \\
1982 \\
1983 \\
1984 \\
1985\end{array}$ & $\begin{array}{l}31.75 \\
29.09 \\
26.62 \\
26.67 \\
26.80\end{array}$ & $\begin{array}{l}34.27 \\
31.74 \\
28.76 \\
28.07 \\
27.52\end{array}$ & $\begin{array}{r}-- \\
30.33 \\
29.37 \\
28.01\end{array}$ & $\begin{array}{l}25.18 \\
21.97 \\
20.14 \\
20.89 \\
20.18\end{array}$ & $\begin{array}{l}0.793 \\
0.755 \\
0.757 \\
0.783 \\
0.753\end{array}$ & $\begin{array}{l}0.735 \\
0.692 \\
0.700 \\
0.744 \\
0.733\end{array}$ & $\begin{array}{r}\overline{-} \\
0.664 \\
0.711 \\
0.720\end{array}$ \\
\hline $\begin{array}{l}1986 \\
1987 \\
1988 \\
1989 \\
1990\end{array}$ & $\begin{array}{l}12.33 \\
16.23 \\
12.20 \\
14.93 \\
18.76\end{array}$ & $\begin{array}{l}13.32 \\
17.28 \\
13.45 \\
16.21 \\
20.80\end{array}$ & $\begin{array}{l}15.04 \\
19.17 \\
15.98 \\
19.69 \\
24.51\end{array}$ & $\begin{array}{r}9.42 \\
13.34 \\
9.79 \\
12.77 \\
16.15\end{array}$ & $\begin{array}{l}0.764 \\
0.822 \\
0.802 \\
0.855 \\
0.861\end{array}$ & $\begin{array}{l}0.707 \\
0.772 \\
0.728 \\
0.788 \\
0.776\end{array}$ & $\begin{array}{l}0.626 \\
0.696 \\
0.613 \\
0.649 \\
0.659\end{array}$ \\
\hline $\begin{array}{l}\text { Average of } \\
1982-1990\end{array}$ & 19.32 & 20.68 & 22.76 & 12.27 & 0.795 & 0.738 & 0.667 \\
\hline
\end{tabular}

FOB crude oil spot prices-annual basis.

$\$ 5 / \mathrm{bbl}$ less than WTI, but the price gap has expanded to about $\$ 7 / \mathrm{bbl}$ since the $1987-1988$ drop in oil prices.

Since thermal heavy oil production is so dependent on being able to maintain long-term steam injection and constant cash flow, fluctuating oil prices, especially at low oil prices, make heavy oil production risky. For independent oil producers, their operation is dependent on being able to sell their oil either at the posted price or under long-term contract which is usually tied to the posted price. If independent producers do not like the local posted price, they have to be able to afford transportation to a market where there is a better price. For light oil, transportation problems are minor as compared to those of heavy oil. However, the margin on heavy oil is low unless oil production, pipelining, refining, and marketing (sales of gasoline) are within a vertically integrated company. California independent heavy oil producers argue that posted prices are abnormally low based on the 15 cents per API degree for oil quality differential. 21 When Alaskan North Slope, imports and California production are combined it is easy to argue that "California has a structurally oversupplied crude market $" 24$

The trends in refinery performance for each of the five Petroleum Administration for Defense Districts (PADD) are shown in Figs. 13 and 14. ${ }^{25}$ Oil production in California has declined recently for both light and heavy oil, but it has been California's heavy oil that has maintained the high level of productivity and that has kept the state progressing. California, along with Alaska, has made PADD 5 a net exporting PADD to other refining districts. Analysis of the trends shown in Figs. 13 and 14 indicates that refineries in PADD 5 as a whole, which includes Alaska, Arizona, 


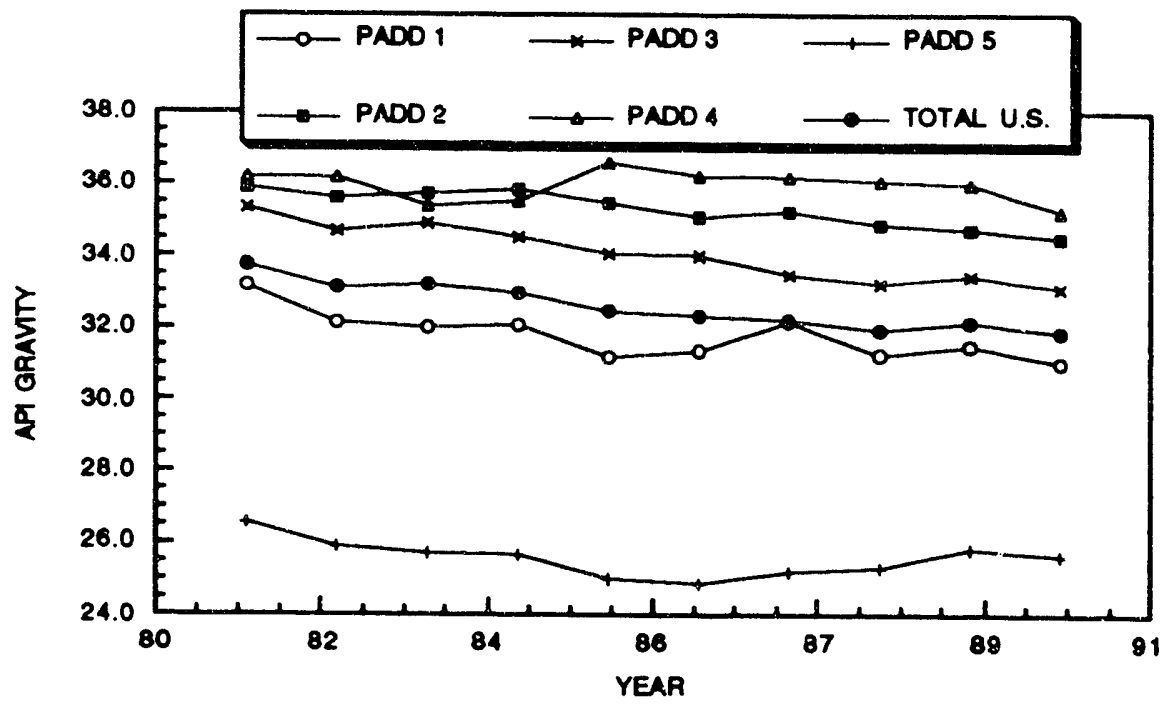

FIGURE 13. - Trends in oil gravity for the past decade in each PADD.

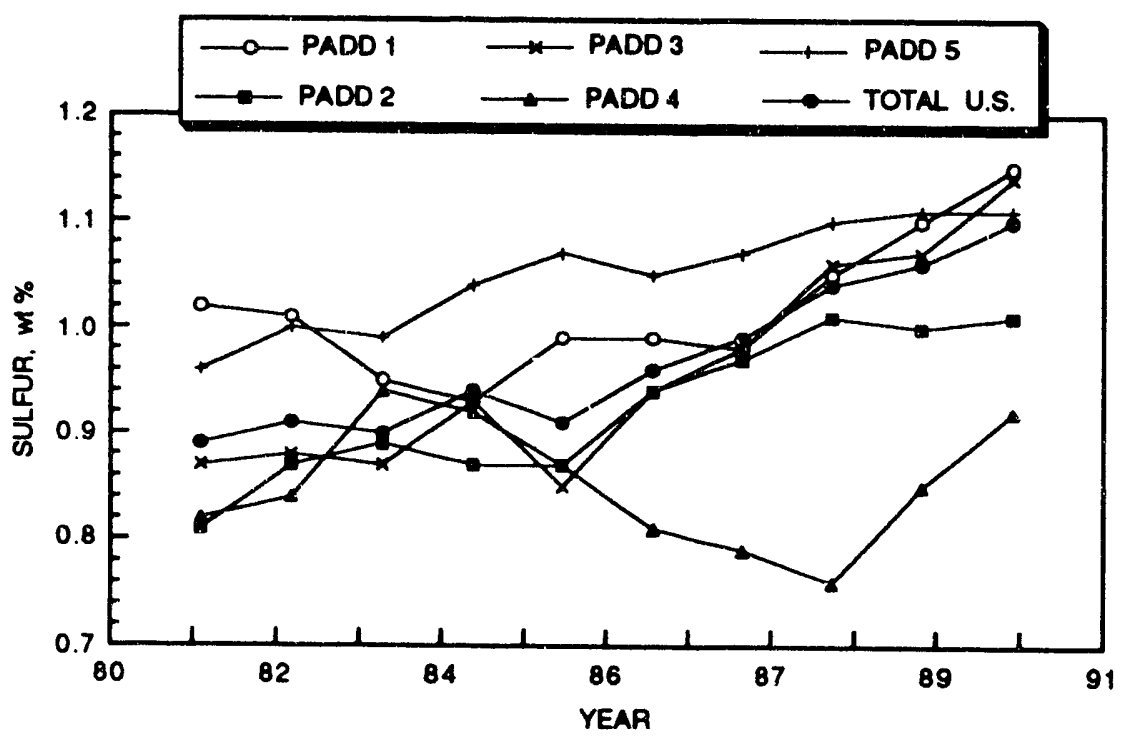

FIGURE 14. - Trends in crude oil sulfur content for the past decade in each PADD.

Hawaii, Nevada, Oregon, Washington and California, typically process the sourest heaviest crude oil as compared to other PADDs or the Nation as a whole. The large California and Washington state refineries are quite different from the small, typically sweet, light oil refineries of the other states comprising PADD 5, (Table 3).16-17 The California refineries have significant heavy oil processing capabilities. 


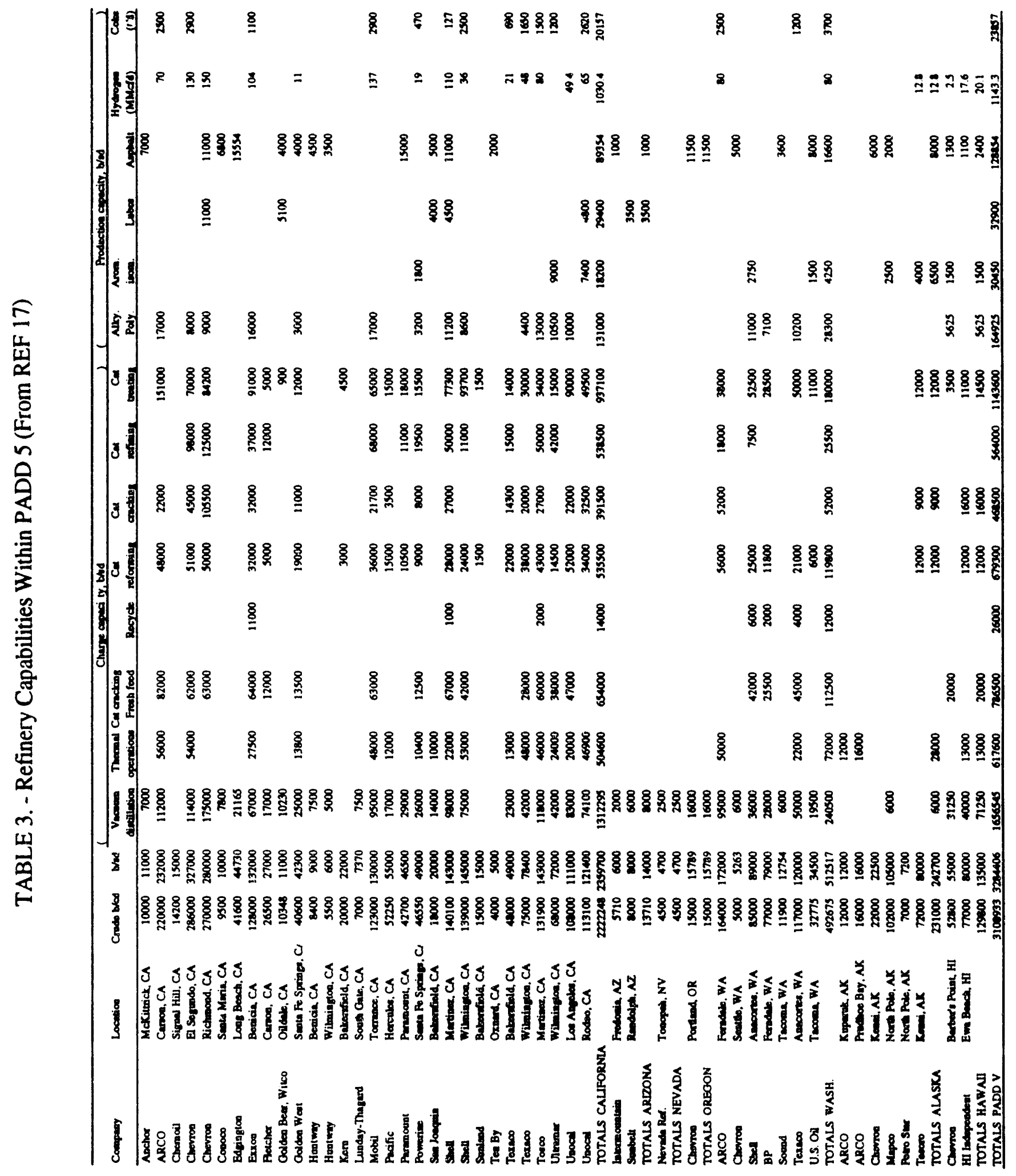


Figure 15 shows the trends in API gravity and sulfur content for both imported and domestic crude oil being refined in the U.S. ${ }^{17,26}$ The trend is toward heavier crude oils with higher sulfur content. Most of the change occurred in the late 1970s and early 1980s. During the last half of the 1980 s, oil gravity fed to U.S. refineries stabilized and reached a temporary plateau that is becoming increasingly dependent upon the quality of imported crude as the volume of imported oil increases and domestic production declines.

A comparison of the magnitude of California production with current U.S. production and demand is shown in Fig. 16. California contributes significant oil. California's total 1990 oil production was 350.7 million barrels or 960,000 BOPD. 4 This volume is $13 \%$ of U.S. production but only $7.5 \%$ of U.S. demand. PADD 5 produces more oil than it consumes, and the API gravity of the crude that is refined in this PADD is significantly lower than that of the rest of the Nation (Fig. 11). During the past decade, the principal refinery capacity in California has been in three areas: the Los Angeles Basin, the San Francisco Bay area, and Bakersfield. The crude oils processed are Alaskan North Slope (ANS at $27^{\circ}$ API gravity and $1.1 \mathrm{wt}-\%$ sulfur), California heavy, California sweet light crude (typically $20^{\circ}$ to $35^{\circ} \mathrm{API}$ at 1.05 to $1.1 \mathrm{wt}-\%$ Sulfur), and imported crude oil. In the past few years, the average API gravity of crude processed in PADD 5 has increased. This has principally been caused by increasing imports of light crudes from Pacific rim countries ${ }^{26}$ and the light oil produced at NPR No. 1.

California has an extensive heavy oil transportation network. ${ }^{21}$ In addition to the major pipelines (Fig. 17), the demand for transport of crude out of the San Joaquin Valley to refineries in the San Francisco area and Los Angeles requires an extensive crude oil truck tanker fleet and an 80,000 BOPD unit train which hauls for Shell. ${ }^{21}$ The access by pipelines to the refinery gate has been argued to be a limiting factor in generating a higher price for San Joaquin Valley heavy crude oil. Until recently, ${ }^{30}$ five of the six pipelines leaving Kern County are proprietary, unregulated, in-state lines owned by major oil companies. ${ }^{21}$ The sixth pipeline, the Four Corner pipeline going to Los Angeles, is an interstate common carrier. Within recent weeks, independent operators have gained access to some of these pipelines based upon a recent California court case. ${ }^{30}$ Two other routes to a refinery cost $\$ 3-\$ 4 / \mathrm{bbl}$ for transport. These two routes to heavy oil refineries on the U.S. Gulf Coast are via the All-America Pipeline or via the Panama Canal by tanker. ${ }^{23}$ Texas offers a price that is discounted about 15 cents per degree API off that of WTI. When the cost of thermal heavy oil production and transport to Texas are added together, the cost to the producer exceeds what a Gulf Coast refiner is willing to pay (delivered imported crude oil is less expensive for the same quality). This leaves little incentive to transport heavy California crude to Texas. In $1990,150,000$ BOPD of ANS were transported to Texas for refining to Gulf Coast and Midcontinent refineries. The recent addition of heavy oil production from the offshore Point 


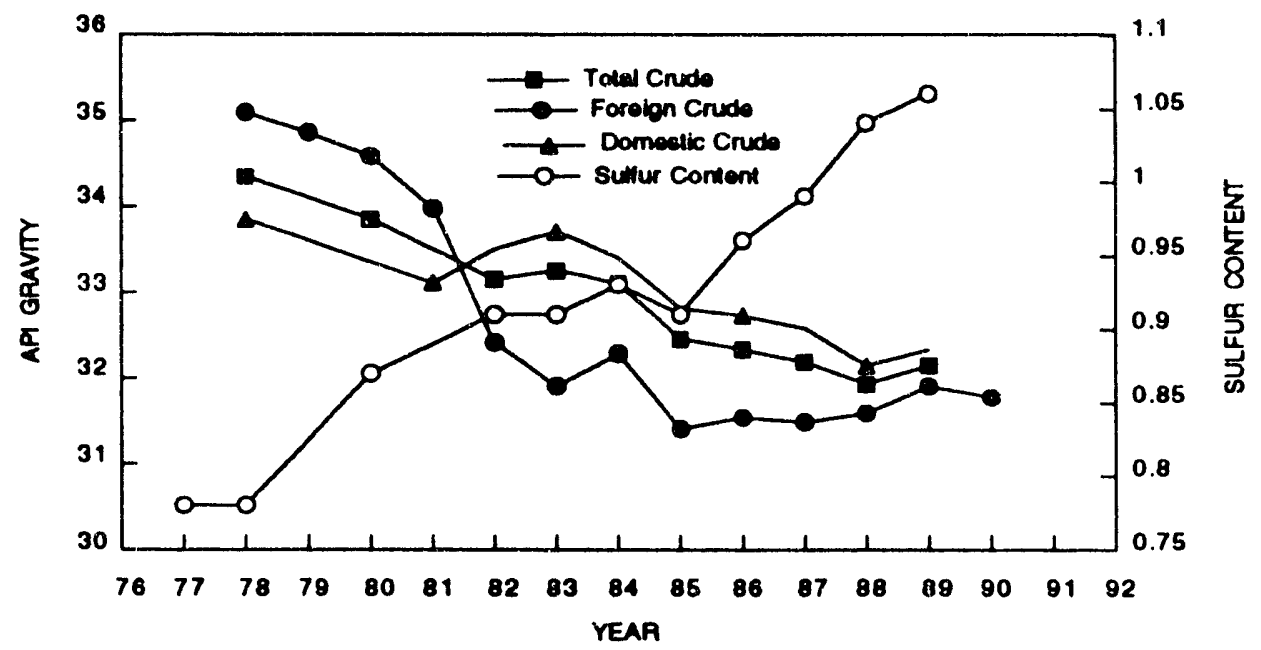

FIGURE 15. - API gravity and sulfur content of domestic and imporfed crude oil being processed in U. S. refineries.

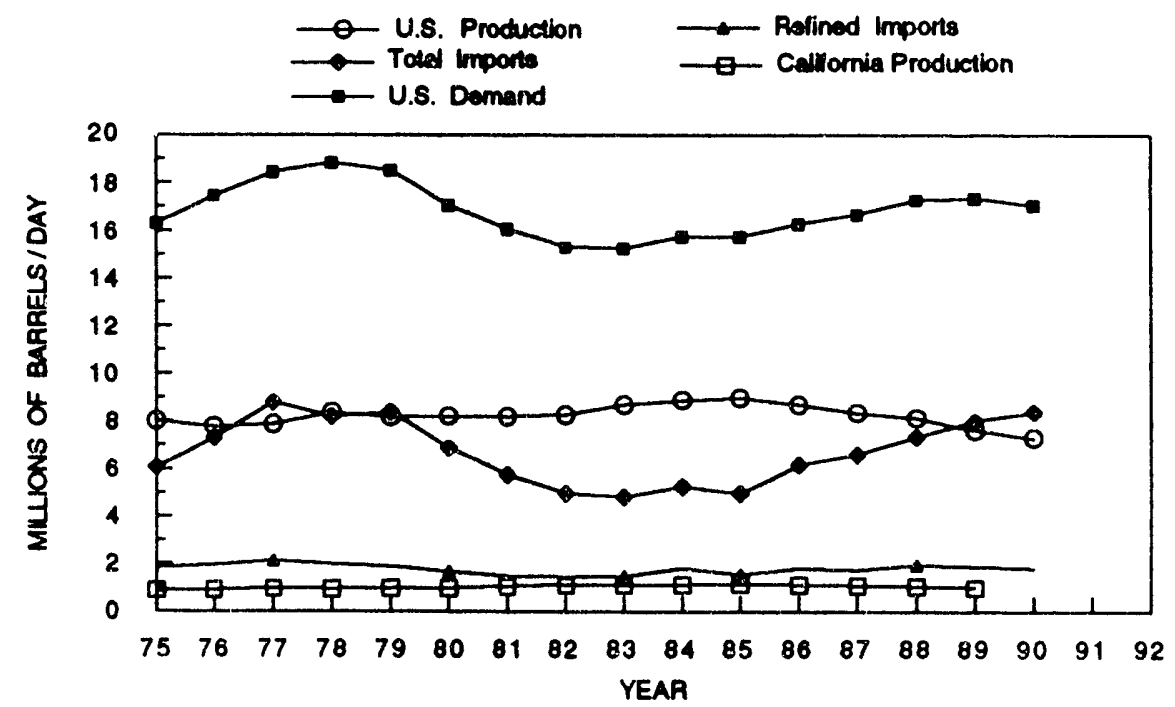

FIGURE 16. - U. S. crude oll demand, imports and U. S. oil production compared to California oil production. 


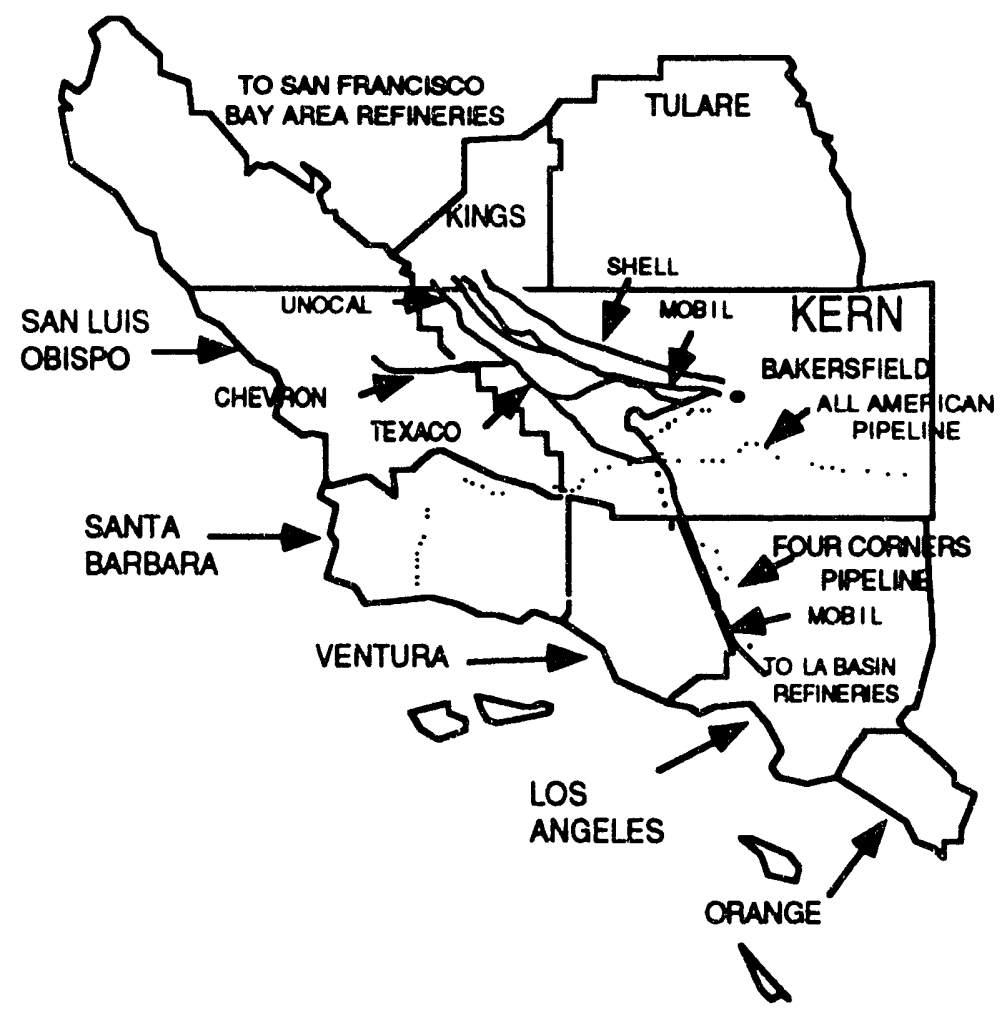

FIGURE 17. - Major Kern County heavy oil pipelines.

Arguello Field adds to the California supply of heavy crude oil and has expanded the price differential between California heavy oil arid WTI. 20 California heavy oil producers, especially non-vertically integrated independent operators, will find economic heavy oil production more difficult.

Within the past few months, three of the small refineries in the Los Angeles Basin closedFletcher, Golden West, and Edgington. These refineries are among about 50 refineries in the U.S. that are expected to close due to uneconomic rates of return. Poor economics in these small refineries is due to inadequate economics of scale, refinery age, cost to implement equipment to meet environmental regulations and, in many areas, the loss of local light sweet crude oil. ${ }^{29}$

The environmental restrictions in California have been the most restrictive in the Nation, and some of the regulations on thermal oil operations have been described by Sarathi. ${ }^{31}$ With the conversion of steam generators from lease crude oil to natural gas, an estimated "...30,000 BOPD of additional heavy crude will be placed on the state's already glutted oil market." 32

California is a major petroleum consuming state, accounting for $11.5 \%$ of U.S. gasoline market in 1989.24 Most of Southern California currently is rated a noncompliance area for air quality. Restrictions on vehicle emissions and from stationary sources, such as steam generators, 
will increase. The call for additional cleaner vehicle fuels (gasoline and diesel) will make refining heavy oil more difficult.

\section{CONCLUSIONS}

California is one of the largest petroleum consuming markets, accounting for $11.5 \%$ of the U.S. gasoline market. California produces 960,000 BOPD (1990) or nearly 13\% of the Nation's total oil production. California is the recipient of most of Alaska's 1.7 million BOPD and most of PADD 5's oil imports. This causes California to have a surplus of oil and makes California a net exporter to other states and PADDs. Heavy oil production within the state now constitutes greater than $70 \%$ of the total oil produced. Each of the three major producing regions, Los Angeles, Coastal, and San Joaquin, have experienced a growth phase, peaked, and then showed a decline in oil production. Each region has peaked at various times throughout the last half century. The opening of the Naval Petroleum Reserve at Elk Hills in 1976 added significant new light oil to California production at a time when other California light oil production had declined greatly. Had it not been for this additional light oil, heavy oil would account for nearly $80 \%$ of the total oil production. Elk Hills production is declining rapidly and may be partially offset by further development of reservoirs within the field and by new offshore production. Elk Hills is a vital part of California's total production.

The California heavy oil industry is dominated by major companies which operate as vertically integrated companies. It is to their benefit to keep the posted price for heavy oil as low as possible and to produce, refine, transport, and market (in company-owned gasoline stations) their own crude and its products. With a large heavy crude resource, a dedicated pipeline, and a refinery tuned to process a specific heavy crude oil, they can obtain acceptable return on investment. If additional crude is needed, they can purchase it at posted prices. The independent heavy oil producer, or a major who is producing an excess of heavy oil that cannot be refined in its own refinery, is at a disadvantage with respect to other majors who have balanced company-owned production with company-owned refining and marketing. Economic production of heavy oil and the transport of heavy oil to refineries outside California is marginal. At the current $\$ 10 / \mathrm{bbl}$ heavy oil price, many independent operators have significantly reduced expenditures. The economic condition is not as bad as that of 1986; however, only the larger fully integrated, balanced (production, refining, and marketing) oil companies can survive the glut of oil and extended low oil prices.

With the import of light crude, the receipt of ANS oil, and new offshore production, the development of additional heavy oil, except by majors which have capacity in their refineries to process their own heavy crude, is unlikely. The profit margin on California heavy oil produced by TEOR processes is small. If world oil prices were to increase, then more heavy oil would be 
produced. When margins are low, as they are at present, heavy oil producers will have to struggle to survive. Major oil companies may have more flexibility. Of critical importance to heary oil development is stable prices, hopefully with less differential between heavy and WTI because ine investment in heat (steam) to maintain future production from a heavy oil reservoir must bc maintained. Additional pressures on environmental issues compound the problem of marginal rate of return, but the petroleum industry in California is leading the Nation in being environmentally conscious. This has not been without significant cost on the rate of return and the demise of some companies.

\section{ACKNOWLEDGMENTS}

This work was sponsored by the U.S. Department of Energy under cooperative agreement DE-FC22-83FE60149 with IITTRI/NIPER as project SGP37. The authors thank the DOE for funding the Associated Western University summer fellowship which supported the work on this project by R. A. Pendergrass II.

\section{REFERENCES}

1. Group of Experts. UNITAR Proposal for the Definition of Heavy Crude and Tar Sands and Addendum, Second International Conference on heavy Oil and Tar Sands, Caracas, Venezuela. February 1981.

2. Moritis, G. $\mathrm{CO}_{2}$ and $\mathrm{HC}$ Injection Lead EOR Production Increase, Biennial EOR Production Report, Oil \& Gas J.. v. 88, No. 17, A pr. 23, 1990, pp. 49-82.

3. National Petroleum Council: Enhanced Oil Recovery, National Petroleum Council, June 1984.

4. Mefferd, M. G. California Department of Conservation. Division of Oil \& Gas, 76th Annual Report of the State Oil \& Gas Supervisor, 1990, No. PR06.

5. Mefferd, .1. (i. California Department of Conservation. Division of Oil \& (jas, 75th Annual Report of the State ( Jil \& Gas Supervisor, 1989, No. PRO6.

6. Mefferd, M. G. California Department of Conservation. Division of Oil \& Gas, 74th Annual Report of the State Oil \& Gas Supervisor, 1988, No. PRO6.

7. Conservation Committee of California Oil \& Gas Producers. Annual Review of California Oil \& Gas Production 1990, Conservation Committee of California Oil \& (ias Producers, Los Angeles, 1991

8. Conservation Committee of California Oil Producers. Annual Review of California Oil Production - 1989. Conservation Committee of California Oil Producers, Los Angeles, 1990.

9. Conservation Committee of California Oil Producers. Annual Review of California Oil Production - 1988, Conservation Committee of California Oil Producers, Los Angeles, 1989.

10. Conservation Committee of California Oil Producers. Annual Review of California Oil Production - 1987. Conservation Committee of California Oil Producers, Los Angeles, 1988.

11. Conservation Committec of California Oil Producers. Annual Review of California ()il and Gas Production. 1990. Pp. $\mathrm{B}-16, \mathrm{I},-4, \mathrm{H}-3$

12 Schmidt, R. L. Thermal linhanced (Dil Recovery - Current Status and Future Needs, Chemical Engineering Progress. January $1990, \mathrm{pp} .47-59$

13. Blcvins, T. R. Steamflooding in the U.S.: A Status Report, J. Pet. Tech., May 1990, pp. 548-554

14. Thrash, L. A. Worldwide Refining Report, Oil \& Gas J., Dec. 23, 1991, p. 64

1.5 (Jil \& (ia.s.). Worldwide Production Report, Dec. 30, 1991, p. 86.

16. Thrash, I. S. Annual Refining Survey. Oil \& (jas J., v. 88, no. 13, March 26, 1990, pp. 77

17. Thrash, 1. S. Annual Refining Survey. Oil \& Gas J., v. 89, no. 11, March 18, 1991, pp. 84

18. Toal, B. A. Cash on the Coast, Oil and Gas Investor, v. 12, No. 1, January 1992, p. 22.

19. Assistant Secretary. Naval Petrolcum and Oil Shate Reserves 1990 . Annual Report of Operations. United States Department of Energy, Iossil Energy, 1991.

20. ()lsen, J). K. Domestic Heavy (jil Projections, Department of Energy Report No. NIPER report in review:

21. Gill, D. "Kern County," Oil \& Gas Investor, August 1990, pp. 1427.

22. Maples, J. W Kern County Assessor. Crude Oil Prices 1991, Kern County, California. Oil and (ias Properties Division, lichruary 1001

23. Oil \& (jas .). U. S. ('rude Prices in Cil \& (jas J. Weekly Production Report, January. 20, 1992, p 71 
24 (irigsby, 1: "Paper and l'encil lixercise or Treble Damages in Kern ('ounty by 1) (iill," (Jil \& (ias Imestor, August $190(1), 519$

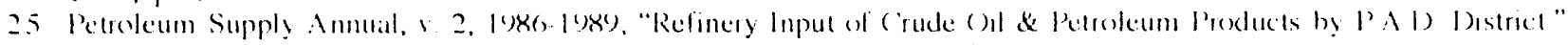
Bnergy Information Agency, (office of () 1 and (jas, l $s$ separtment of Energy.

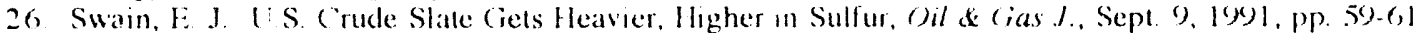

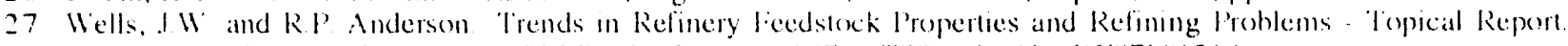
Department of Inergy Report No. NIPER-186, Jamuary 1987. N'IS order No. DH:87()(012/4

28. American Petroleum Institute Basic Petroleum Data Book-Petroleum Industry Statistics, Section V'II, Table 2, "Irotal I nited States Supply and Demand For All ( Dils." v. XI, No. 1. January 1991.

29 Olsen, D. K. and E. B. Ramzel. Heavy Oil Refining and Transportation: leffect on the Jeasibility of lncreasing Domeste Heary ( ) Production, presented at the Eastem () Shale/Tar Sands/lleavy ()il Symposium. I niversity of Kentucky, lexungton Kl, Nor 1.3.15. 1991.

30. Oil and Cias lmestor. Y 12, No 1, danuary 1992, p. 7.

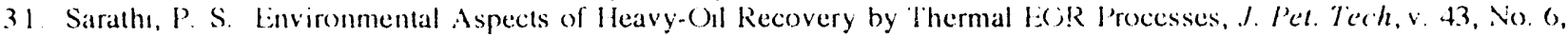
Iune, 1991, p.662.

32. Itoffman, J quoted in (sil and (jas Investor, v. 12, No. 1, January 1992, p. 7

*U.S.GPO: $1992-661-026 / 60036$ 

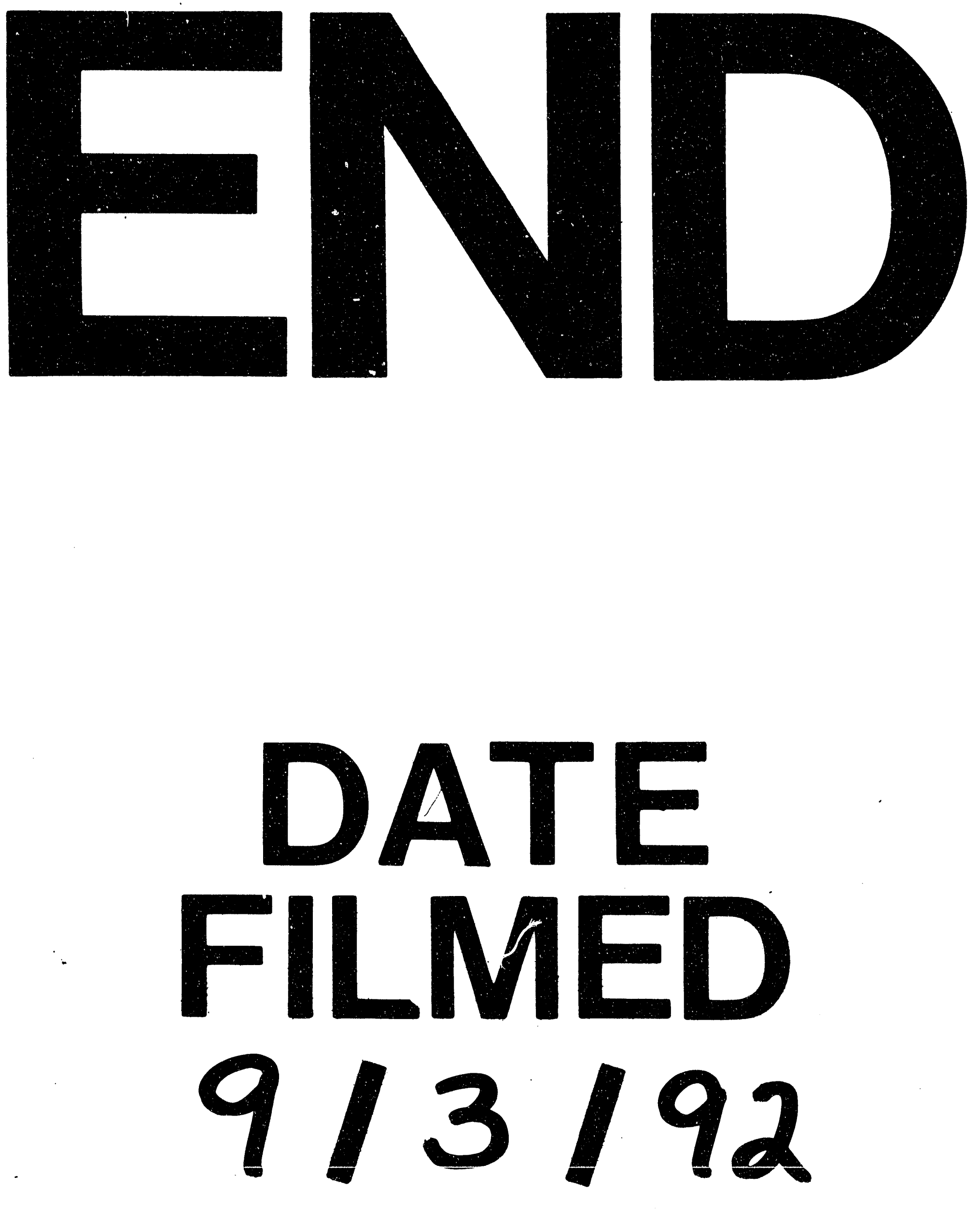

f 
